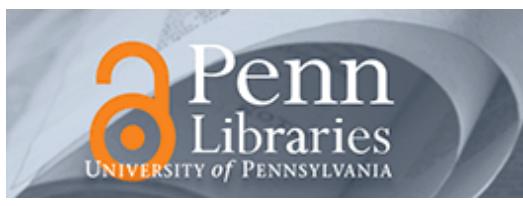

University of Pennsylvania ScholarlyCommons

Wharton Pension Research Council Working Papers

Wharton Pension Research Council

$9-1-2013$

\title{
An Actuarial Perspective on Pension Plan Funding
}

Donald J. Segal

Society of Actuaries

Follow this and additional works at: https://repository.upenn.edu/prc_papers

Part of the Economics Commons

Segal, Donald J., "An Actuarial Perspective on Pension Plan Funding" (2013). Wharton Pension Research Council Working Papers. 119. https://repository.upenn.edu/prc_papers/119

This paper is posted at ScholarlyCommons. https://repository.upenn.edu/prc_papers/119

For more information, please contact repository@pobox.upenn.edu. 


\title{
An Actuarial Perspective on Pension Plan Funding
}

\begin{abstract}
The Pension Benefit Guaranty Corporation (PBGC) was established by the Employee Retirement Income Security Act (ERISA) to provide "insurance guarantees" for qualified pension plans insufficiently funded to provide accrued vested benefits. The PBGC's annual reports on the liabilities for plans it has taken over and the agency's assets show that the Single Employer Program has seen this "net position" vary from a surplus of almost $\$ 10$ billion in 2000, to a deficit of over $\$ 29$ billion in 2012. The PBGC uses a proprietary Pension Insurance Modeling System to model future scenarios for their obligations. This paper offers observations on future pension plan funding and how this could affect the PIMS model, based on the current environment, and how the agency might respond to change.
\end{abstract}

\section{Disciplines}

Economics 


\title{
An Actuarial Perspective on Pension Plan Funding
}

\author{
Donald J. Segal
}

September 2013

\author{
PRC WP2013-13 \\ Pension Research Council Working Paper \\ Pension Research Council \\ The Wharton School, University of Pennsylvania \\ 3620 Locust Walk, 3000 SH-DH \\ Philadelphia, PA 19104-6302 \\ Tel.: 215.898.7620 Fax: 215.573.3418 \\ Email:prc@wharton.upenn.edu \\ http://www.pensionresearchcouncil.org
}

The research reported herein was pursuant to a grant from the US. Social Security Administration (SSA) funded as part of the Retirement Research Consortium (RRC); the author also acknowledges support from The Pension Research Council at The Wharton School. All findings and conclusions expressed are solely those of the author and do not represent the views of the SSA or any agency of the federal government, the PRC, or The Wharton School at the University of Pennsylvania. In addition, the opinions expressed by the author do not represent those of the Society of Actuaries or any other organization of which I am a member. All findings, interpretations, and conclusions of this paper represent the views of the authors and not those of the Wharton School or the Pension Research Council. (C2013 Pension Research Council of the Wharton School of the University of Pennsylvania. All rights reserved. 


\title{
An Actuarial Perspective on Pension Plan Funding
}

\begin{abstract}
$\underline{\text { Abstract }}$
The Pension Benefit Guaranty Corporation (PBGC) was established by the Employee Retirement Income Security Act (ERISA) to provide "insurance guarantees" for qualified pension plans insufficiently funded to provide accrued vested benefits. The PBGC's annual reports on the liabilities for plans it has taken over and the agency's assets show that the Single Employer Program has seen this "net position" vary from a surplus of almost $\$ 10$ billion in 2000, to a deficit of over $\$ 29$ billion in 2012. The PBGC uses a proprietary Pension Insurance Modeling System to model future scenarios for their obligations. This paper offers observations on future pension plan funding and how this could affect the PIMS model, based on the current environment, and how the agency might respond to change.
\end{abstract}

\section{Donald J. Segal}

Penultimate Past President

Society of Actuaries

19 Sunset Place

Emerson, NJ 07630-1725 


\title{
An Actuarial Perspective on Pension Plan Funding
}

\author{
Donald J. Segal
}

The Pension Benefit Guaranty Corporation (PBGC) is a federal agency established by the Employee Retirement Income Security Act (ERISA), whose purpose is to provide “insurance guarantees” up to a certain level for qualified pension plans unable to continue in existence and not funded to a level sufficient to provide accrued vested benefits to their participants and beneficiaries. Each year the PBGC issues a report on the liabilities for plans it has taken over and the assets that the agency has on hand to provide those benefits. The Single Employer Program has seen this “Net Position” vary from a surplus of almost $\$ 10$ billion in 2000, to a deficit of over $\$ 29$ billion in 2012.

The reasons behind this variance are many and complex. The PBGC has been employing a proprietary system, the Pension Insurance Modeling System (PIMS), to model future scenarios for their obligations. Other experts will address the intricacies and assumptions inherent in this system. Here I offer my observations on future pension plan funding and how this could affect the PIMS model.

The PBGC confronts many risks. Can these risks and potential changes be included in the model? If an objective is to make the agency more resilient, then this is what could be done and what could be recognized in the PIMS model. My thoughts here do not represent an exhaustive analysis of the funding requirements under Internal Revenue Code Sections 412 and 430. Rather, I scan the current environment for pension plan funding, to provide an idea of what might be proper. My focus is less on how to improve the environment, but more to explore on how the agency might respond to change. 
The issue can be stated very simply. To improve funding in the private sector qualified pension plan system in the United States, sponsors must put more money into the plans. Ideally, every plan should be funded to the point where assets are equal to actuarial liabilities for benefits accrued to date. Then if the PBGC took over a plan because the plan sponsor was unable to continue in business, or filed for bankruptcy, the risks assumed by the PBGC would be relatively low. If it only were that simple!

There are many facets to the issue of funding defined benefit (DB) pension plans in the United States today, including the following:

- Assets yields have been fluctuating widely and wildly, although the equities market is now at a record high;

- $\quad$ Bond yields are at record lows;

- $\quad$ The interest rate environment is uncertain because of federal policy;

- Congress last year reduced minimum funding requirements to raise revenue for other purposes;

- Plan sponsors are unhappy with the way pension expense has been hitting the balance sheet because of the unstable and generally declining interest rate environment; and

- Plan sponsors are freezing and/or terminating DB plans because of the volatility in the pension expense.

There is also the basic issue of what to do with the existing PBGC deficit. The current PIMS model considers these variables and models various possible future scenarios. 


\section{The Current Environment}

Large corporate pension plans in the United States are currently not well funded. Several studies exist exploring the relationship between assets and liabilities for a selected universe of plans. For example, the Milliman (2013) Corporate Pension Funding Study looked at 100 U.S. public companies with the largest DB pension plan assets, ${ }^{1}$ and it found that the excess of projected benefit obligations over market value of assets (the "funding deficit") stands at a record high. The year-end discount rate also fell to a record low (4.02\%). The funded ratio of assets to projected benefit obligations (PBO) was also at a record low, despite excellent 2012 market returns above expected returns and large contributions. And the pension expense for this universe was at a record high.

As an example, in the footnotes to the 2012 AT\&T annual statement (AT\&T 2012: 44), the company stated that for the year ending December 31, 2012, it decreased its discount rate by $1.00 \%$, resulting in an increase in the pension plan benefit obligation of $\$ 7.0$ billion. For the year ending December 31, 2011, it decreased the discount rate by $0.50 \%$, resulting in an increase in the pension benefit obligation of $\$ 3.4$ billion. As another example, the footnotes to IBM's annual statement for 2012 (IBM 2012) stated that the decrease in the discount rate by $0.80 \%$ resulted in an increase in the PBO of $\$ 3.4$ billion; for the year ending December 31, 2011, the decrease in the discount rate of $0.60 \%$ resulted in an increase in the PBO of $\$ 4.2$ billion. When interest rates go up, these numbers will reverse, but meanwhile, the pain persists. The same is happening with funding (but more about that later).

\footnotetext{
${ }^{1}$ The 2013 report covered plans for which a 2012 annual report was released by March 7, 2013.
} 
What this all points out is that the record low interest rates are killing DB pension plans, discouraging sponsors from maintaining them (because of the "hit" on the balance sheet), and boosting the deficit of the PBGC.

The FY 2012 PBGC Exposure report (PBGC 2012) comments in several places on the effect that interest rates have had on the PBGC deficit and For instance, the agency stated: “Interest rates affect how we calculate obligations... Changes in this interest rate have a big effect on these calculations." In the Overview of PIMS, again we see "Changes in interest rates have a big effect on this calculation - the higher the interest rate by which we calculate what we owe, the lower the present value of the obligations (liabilities) reported on our balance sheet.” The current PIMS addresses these variables.

\section{The PBGC Deficit and Legacy Costs}

The PBGC Annual Reports and Data Books (PBGC 2013a,b,c) show that the net financial position of the PBGC Single-Employer Program for 1980 through 2011 (assets/liabilities) has varied from a low of $31.3 \%$ in 1986 , to a high of $187.2 \%$ in 2000 . This picture obviously depends on the interest rate environment and the status of financial markets, generally. Since 2002, the funded ratio has been below 90\%. And the PBGC Annual Reports show that the interest factors used to value the PBGC Single-Employer Program liabilities declined well over 300 basis points from 2008 to 2012 (6.66\% for 20 years, 6.47\% thereafter in 2008, to $3.28 \%$ for 25 years, $2.97 \%$ thereafter for 2012 ).

A major concern is the PBGC deficit, more specifically the "legacy cost," as opposed to the ongoing cost. As referred to above, PBGC liabilities have grown faster than its assets in recent years, due to the decline in interest rates. The PBGC 2012 Annual report showed a one- 
year increase of more than $\$ 10$ billion in liability due to the decline in interest rates. The PBGC defines the term "underwriting gain or loss" to be equal to its premium income minus all administrative expense and the unfunded liability of plans for which it assumes responsibility during a year. So even if the premium structure, as amended by recent legislation, were sufficient to support any new obligations assumed by the PBGC, the deficit arising from past plans assumed remains problematic.

A key question is whether it is good insurance practice to ask current "policyholders," i.e., those sponsors who currently have ongoing DB plans, to pay claims for policyholders of past generations. No insurance company would last, based on this premise. Maintaining a system that requires current plan sponsors to pay for this legacy deficit from the past will only serve to encourage these plan sponsors to terminate their DB plans and leave the system.

The American Academy of Actuaries (2012) has addressed this issue, defining goingforward costs as those associated with the risks of ongoing coverage by the PBGC, excluding legacy costs. Legacy costs were defined as those that associated with existing or imminent claims, such as plans for which the PBGC has already assumed liability or that it is expected to assume in the near future. The important actuarial principle states that, "Applying basic insurance principles, premiums for going-forward costs should be adequate and appropriately risk-related. The traditional insurance model, however, does not adequately address legacy costs.” The Academy went on to observe that adequate premiums must fully cover expected going-forward claims and administrative costs. The risk-related premium should reflect the relative insurance cost of a plan, the extent of the PBGC's potential obligation, and the probability of the PBGC assuming that obligation (a classic insurance approach). But the Academy also observed that legacy costs already incurred are clearly not insurable events, and 
these are not associated in any meaningful way with ongoing plan sponsors contributing into the system: “That group would not bear the legacy costs in an insurance model; if they did, the price of the insurance would exceed the true value of the coverage, and thus provide a market incentive for the insured to decline coverage or move their business to another insurer.”

But this is exactly what is happening. Plan sponsors with existing DB plans are exiting the system. Among the reasons is the legacy cost they are being asked to bear. The Academy Issue Brief then goes on to suggest several options for allocating this legacy cost, including to assign the full legacy cost to current plan sponsors, spread over a number of years (the current approach); or to assign only a portion of the legacy cost to current plan sponsors and find another source of funds.

An added function of PIMS could be modeling various alternatives for addressing the issue of legacy costs vs. ongoing costs. Congress has granted the PBGC increased authority over premiums, so PIMS must model the effect of various schemes for increasing premiums and the effect on the financial health of the PBGC.

\section{Encouraging the Formation of New Defined Benefit Plans}

If we are concerned about the funding of DB plans and the concomitant health of the PBGC, one solution is to encourage the formation of new DB plans. To this end, several recent surveys indicate that employees remain very interested in having a DB pension. If an employer offers a DB plan, this is more attractive than only having a defined contribution (DC) plan where 
the entire investment risk is on the employee. The idea of a benefit payable for life is becoming more attractive to employees as they start thinking about retirement, even at younger ages. ${ }^{2}$

For instance, the National Institute of Retirement Security (2013) recently found that Americans are highly supportive of traditional (DB) pensions. Some $83 \%$ of those surveyed reported favorable views of pensions, and $82 \%$ felt that retirees with DB plans were more likely to have a secure retirement. Among Millennials, 89\% believed that those with DB pensions would have a more secure retirement than those without, and $94 \%$ said that the lack of pensions for Baby Boomers is creating stress for families and the economy.

Thus far, PIMS does not explicitly recognize the formation of new DB plans. Accordingly, we believe it useful to briefly look at the kinds of DB plans that may be adopted in the future and how PIMS could adjust for them. We know that many employers say they do not want to face the cost unpredictability of DB plans. Looking back into the past, however, we find that the cost of career average plan formula (also known as a current pay plan) can be just as predictable as a DC plan. In fact, this can be even more predictable than a 401(k) match, because the latter depends on employee behavior which is unpredictable. A plan sponsor wishes to know what the plan cost will be, each year. While there is mortality risk, actuaries can model that. There is investment risk, but investment managers can help with that.

Cash balance plans may be an attractive way to manage these risks in the future. Since the passage of the 2006 Pension Protection Act (PPA), cash balance plans can credit earnings

${ }^{2}$ We do not elaborate here on the shortcomings of defined contribution plans including the employee bearing investment risk, leakage, and insufficient money being put away for retirement. In fact, leakage is one of the major impediments to saving for retirement, as the money intended for retirement may be spent on houses, debt, education, vacations, etc. 
credited to each participant's account based on plan's trust fund return, subject to a floor of zero. One can also put a maximum on the rate credited. A good design will have both the floor and ceiling determined on a cumulative basis, not year-by-year. In this way, the investment gain or loss can be minimized over time, and the funding effect can be spread over a few years where it will ideally even out. In other words, there should be a good match between employer contributions and new liabilities in these new plans. This can lessen the risk borne by the PBGC (not to mention the premium income) and improve funded ratios. With a career average plan, the sponsor decides if and when he will put in a past service update. The career average plan does not have the "blank check" aspects of a plan where the formula is based on final average earnings. When the sponsor puts in a past service update, he will know exactly what it will cost.

Another way to implement good plan design is to eliminate lump sum payments. Sponsors may encourage lump sums because it removes the plan's liability off the firm's books and reduces PBGC premiums. But most would agree that this is not good retirement income design.

Still a different approach would move to a contributory DB plan. Under current law, employee contributions in corporate plans are on a post-tax basis. Changing the law to permit (and encourage) employee contributions to DB plans on a pre-tax basis (as is done with 401(k) plans) would help. Among other desirable effects, such as the employee helping to fund the plan, this would omit that ugly exclusion ratio calculation at retirement, wherein the portion of the benefit that is non-taxable is determined.

An even more radical idea would be to change the law to permit employer matches to employee 401(k) deferrals to be made as accruals in a DB plan. 
All of these ideas could help bring back DB plans, which would be potentially attractive to the PBGC and good for employee retirement planning. PIMS could readily be modified to model future changes such as these.

\section{“Derisking” of Defined Benefit Plans: Effects on Large Pension Plan Sponsors}

One idea spreading among large pension plan sponsors is "derisking," that is offering lump sums and annuity purchases to retired and vested terminated participants and beneficiaries. Three notable implementers of this practice in 2012 were Ford, General Motors, and Verizon. The idea is to get the plan's liability off the plan sponsor's books, thereby lowering the actuarial and investment risks and passing them on to a reliable third party (a large, stable insurance company). Derisking also lowers subsequent PBGC premiums paid by plan sponsors. Speaking in actuarial terms, there is an interplay between the amount of the lump sums paid, the cost of the annuity purchase, and the liabilities held for both funding and accounting purposes. Often, the amount paid out can exceed the liabilities held, because of the difference in actuarial assumptions used.

The Milliman Corporate Pension Funding Study (2013) noted that, despite a \$45 billion reduction in plan obligations due to these activities across their universe, total pension obligations were at a record high because of the decline in discount rates used to measure ongoing obligations. In the short term at least, because of this “assumption whipsaw,” derisking 
strategies may not reduce the apparent actuarial unfunded accrued liability and the PBGC variable rate premium owed by plan sponsors. $^{3}$

An interesting side note is that Verizon retirees filed a class-action suit over the transfer of the obligation from Verizon to Prudential in November 2012, claiming that the conversion to an annuity would strip participants of the protections of federal law. In March 2013, a federal judge ruled that the suit could proceed, and as of this writing, it is unclear if this suit will add to the PBGC's risk. This development, and other similar ones, must be integrated into a longer-term overhaul of the PIMS modeling framework.

\section{Future DB Plan Contributions}

MAP-21 provided for interest rate relief in the minimum funding requirements under ERISA for qualified DB plans, as a revenue raising measure for the federal government. But this will not really produce long-term relief, as it merely changed the pattern of the employer contributions to pensions. Only reducing this year's contributions just increases future contributions.

Prior to the passage of the legislation, a Society of Actuaries (2012) study used the PIMS model to undertake projections evaluating the MAP-21 changes. Among its major findings were that aggregate contributions requirements would initially be significantly lower than under current law, but they would be expected to rise each year until they ultimately exceeded the amounts that would have been required under current law. Moreover, the percent of obligations

${ }^{3}$ The PBGC per capita premium which is rising and will continue to rise as a result of the Moving Ahead for Progress in the 21st Century Act [MAP-21]. The PBGC per capita premium, which was \$19 as recently as 2005, will be \$49 in 2014 (adjusted for inflation thereafter). 
funded would fall in the short term due to lower contributions, but it would eventually return to the levels expected under current law as contributions increase thereafter. In other words, the bill was predicted to have significant short-term effects of lowering contribution requirements and funded levels, but it did not address longer term volatility and long-term contribution concerns. The report also noted that, to the extent that plans defaulted during this period of the lag in contributions, there would be greater claims on the PBGC. It is unclear whether and how the PIMS model recognizes such law changes affecting future funding.

\section{Actuarial Standards}

It is also worth noting that actuarial standards play a key role in this discussion. Minimum funding requirements for qualified pension plans are set by statute. Over the years, actuarial discretion in selecting assumptions has been restricted, as the law now dictates interest rates and mortality rates for funding. The actuary’s judgment is now limited to turnover rates, retirement ages, and forms of benefits (though everything in aggregate must be reasonable in the judgment of the actuary). Beyond the requirements of the law, a good actuary will also discuss a long term funding policy with the plan sponsor to provide for reasonable, stable, long-term funding costs that will satisfy the minimum requirements of the law.

Actuarial standards of practice require disclosure of all assumptions, methods, data used, etc. in presenting results and advice. Reasonableness of assumptions cannot merely be claimed. For major assumptions, the actuary needs to go through a process to come up with a reasonable assumption and often this calls for some degree of quantification. For an actuary, coming up with a funding recommendation or policy means more than just generating the numbers. It also 
involves an assessment of the short- and long-term effects of what is being recommended, seeking to ensure the long-term sound funded status of the plan.

\section{Conclusions}

The outlook for future funding of DB plans depends on several factors. The Internal Revenue code and ERISA, as modified by Congress periodically, dictate minimum funding requirements. But to see a real improvement in the funded ratios of private pension plans and of the PBGC's net position, there will have to be a recovery (meaning an increase) in Treasury bond rates and corporate bond rates. These are the drivers in the valuation of liabilities, and PIMS currently models these scenarios.

Yet even more critical to the survival of the PBGC and the defined benefit pension model would be a new approach to plan design. In our view, this could encourage DB maintenance and new plan formation. Pension designs of the career average variety are less susceptible to variations in market performance and much more predictable in cost and expense. Sensitivity analysis with PIMS would help evaluate how such changes can shape the future of the DB plan world and its insurance provider. 


\section{References}

American Academy of Actuaries (2012). Examining the PBGC Premium Structure. Issue Brief (April). Washington, DC: American Academy of Actuaries. http://www.actuary.org/files/publications/IB_on_PBGCPremium_120426.pdf

AT\&T (2012). AT\&T Inc. 2012 Annual Report. Dallas, TX: AT\&T. http://www.att.com/Investor/ATT_Annual/2012/downloads/ar2012_annual_report.pdf

IBM (2012). 2012 IBM Annual Report. Armonk, NY: IBM.

http://www.ibm.com/annualreport/2012/bin/assets/2012_ibm_annual.pdf

Milliman (2013). 2013 Corporate Pension Funding Study. Seattle, WA: Milliman. http://www.milliman.com/expertise/employee-benefits/products-tools/pension-funding$\underline{\text { study/ }}$

National Institute of Retirement Security (NIRS) (2013). Pensions and Retirement Security 2013: A Roadmap for Policy Makers. Washington, DC: NIRS.

Pension Benefit Guaranty Corporation (PBGC) (2012). FY 2012 PBGC Exposure Report. Washington, DC: PBGC. http://www.pbgc.gov/documents/2012-exposure-report.pdf

Pension Benefit Guaranty Corporation (PBGC) (2013a). PBGC Annual Report [1996-2012]. Washington, DC: PBGC. http://www.pbgc.gov/res/annual-reports.html

Pension Benefit Guaranty Corporation (PBGC) (2013b). Pension Insurance Data Book [19962011]. Washington, DC: PBGC. http://www.pbgc.gov/res/data-books.html

Pension Benefit Guaranty Corporation (PBGC) (2013c). Pension Insurance Data Tables [20102011]. Washington, DC: PBGC. http://www.pbgc.gov/res/data-books.html 
Society of Actuaries (SOA) (2012). Proposed Pension Funding Stabilization: How Does It Affect the Single-Employer Defined Benefit System? Schaumburg, IL: SOA. 